$\begin{array}{cc}\text { Türkiye Tarımsal Araştırmalar Dergisi } & \text { Turk J Agric Res } \\ \text { dergipark.gov.tr/tutad } & \text { O17, 4(1): 71-78 } \\ \text { O TüTAD } & \begin{array}{l}\text { ISSN: 2148-2306 } \\ \text { e-ISSN: 2528-858X } \\ \text { doi: } 10.19159 / \text { tutad.300711 }\end{array}\end{array}$

\title{
Tuz Etkisi Altındaki Domates Bitkisinde Potasyum ve Kalsiyum Antioksidatif Sistemi Etkiler mi?
}

\author{
Atilla Levent TUNA ${ }^{1 *}$, Mahmut YILDIZTEKIN ${ }^{2}$, Sultan KÖŞKEROĞLU ${ }^{1}$, İbrahim YOKAŞ ${ }^{3}$ \\ ${ }^{\prime}$ Muğla Sttki Koçman Üniversitesi, Fen Fakültesi, Biyoloji Bölümü, Muğla, TÜRKIYE \\ ${ }^{2}$ Muğla Sitki Koçman Üniversitesi, Köyceğiz Meslek Yüksekokulu, Tibbi ve Aromatik Bitkiler Bölümü, Muğla, TÜRKIYE \\ ${ }^{3}$ Muğla Sitki Koçman Üniversitesi, Ortaca Meslek Yüksekokulu, Bitkisel ve Hayvansal Üretim Bölümü, Muğla, TÜRKIYYE
}

\begin{abstract}
Geliş Tarihi/Received: 22.10 .2016
Kabul Tarihi/Accepted: 04.12.2016

"Sorumlu Yazar/Corresponding author: tuna@mu.edu.tr

Özet: Sera koşullarında yürütülen bu çalışmada, tuz stresi altındaki domates bitkisinde (Lycopersicon esculentum Mill.) antioksidatif sistem, prolin, relatif su kapsamı (RSK, \%), membran geçirgenliği (MG, \%) ve kuru madde (KM, \%) üzerine potasyum (K) ve kalsiyum (Ca) bileşiklerinin etkileri araştırılmışıtır. Tuz; $\mathrm{NaCl}$ formunda 3 ayrı konsantrasyonda (50, 100 ve $150 \mathrm{mM}$ ), $\mathrm{K}$ ve Ca ise $20 \mathrm{mM}$ konsantrasyonlarında uygulanmıştır. Domates bitkisine tuz ile ilave olarak verilen potasyum ve kalsiyumlu bileşikler antioksidatif sistemi regüle etmiş, tuzun arttırdığı lipit peroksidasyonu düşürmüş ve tuzun olumsuz etkilerini azaltarak RSK, MG ve KM üzerinde iyileştirici etkiler yapmıştır. Tuz stresi altında yetiştirilen domates bitkisine uygulanan $\mathrm{Ca}$ ve K'lu bileşiklerin, stres etkilerini hafifleterek bitkinin gelişimini destekleyebileceği yargısına varılmıştır.
\end{abstract}

Anahtar Kelimeler: Domates, tuzluluk, potasyum, kalsiyum, antioksidatif sistem

\section{Does Potassium and Calcium Affect the Antioxidative System of Tomato Plant Under Salt Effect?}

\begin{abstract}
In this study which was conducted under greenhouse conditions, the impacts of calcium and potassium compounds on the \% DM (dry matter) and \% EC (electrical conductivity), \% RWC (relative water content), and proline, antioxidative system in tomato plant (Lycopersicon esculentum Mill.) under salt stress were investigated. Three different concentrations of salt $(50,100$ and $150 \mathrm{mM}$ as $\mathrm{NaCl})$ and potassium and calcium $\left(20 \mathrm{mM}\right.$ as $\mathrm{KNO}_{3}$ and $\left.\mathrm{CaNO}_{3}\right)$ were applied. The compounds of $\mathrm{Ca}$ and $\mathrm{K}$ which were given in tomato plants in addition to salt, were regulated to antioxidative system, decreased lipid peroxidation increasing with salt and ameliorated $\mathrm{RWC} \%, \mathrm{EC} \%$ and $\mathrm{DM} \%$ by reducing the detrimental effects of salt. Based on these results, it was concluded that $\mathrm{Ca}$ and $\mathrm{K}$ compounds applied to tomato plant grown under salt stress, supported plant growth and mitigated stress effects.
\end{abstract}

Keywords: Tomato, salinity, potassium, calcium, antioxidative system

\section{Giriş}

Bitkilerde yaşamlarının herhangi bir döneminde çevresel faktörlerin etkisiyle ortaya çıkabilen ve metabolizmayı olumsuz etkileyerek gelişmeyi duraklatma ya da sonlandirma kuvvetine sahip her türlü etken stres olarak adlandırılabilir. Tarım yapılan toprakları etkileyen tuzluluk, bir abiyotik stres tipi olup, lokal tarımsal ekosistemlerde ürün verimini kisitlayan veya tarım topraklarını tamamen atıl hale getiren önemli bir global problem haline gelmiş bulunmaktadır. Bugün dünyada toplam tarım arazisi varlığının yaklaşık $\%$ 13'ü tuzdan etkilenmiş durumda olup, yaklaşık 100 'e yakın ülkede tarımsal tuzluluk problemi mevcuttur. Türkiye'deki duruma bakıldığında, 
yaklaşık 4 milyon ha alanda tuzluluk problemi veya tehdidi bulunduğu bildirilmektedir (Koyuncu, 2012).

Kültür bitkilerinde toprak ortamındaki suda çözünebilir total tuz konsantrasyonu gelişme ortamının tuz yoğunluğunun saptanmasında kullanılan önemli bir tespit birimidir. Kültür bitkileri gelişme ortamının EC'sine (membran geçirgenliği) hassas ve dirençli arasında oldukça geniş bir fazda tepki vermektedir. $\mathrm{Bu}$ oran genellikle EC 1 ila EC 8 arasında değişim gösterir. Örneğin, domates bitkisinin eşik EC dayanım değeri 2.5 iken, bu oran 3.5, 5.0 ve 7.6 olduğunda domates bitkisinin veriminde meydana gelecek verim azalması sirasiyla \% $10, \% 25$ ve $\% 50$ olacaktır (Amacher ve ark., 2000).

Tuzlu şartlarda toprak çözeltisinin ozmotik potansiyelinin düşmesi ve buna paralel olarak su potansiyelindeki azalma neticesinde bitki su alımı azalmaktadır. Tuzlu ortamda yetiştirilen bitkilerde verim kaybını önlemek ve bozulan ozmoregülasyonu yeniden sağlamak temel hedef olmalıdır. Tuz stresine maruz kalmış bitkilerde verimdeki düşüş her ne kadar ortamda bulunan sodyum $(\mathrm{Na})$ ve benzeri katyonların direkt toksik etkisine bağlı ise de, diğer bir nedeni de iyon dengesindeki bozulmadır. Tuz stresinde ortamda yüksek seviyelere ulaşan $\mathrm{Na}$ ve klor (Cl), potasyumun, kalsiyumun ve azotun alınımını azaltarak bitkilerin iyon dengesinin bozulmasına neden olabilmektedir (Güneş ve ark., 1994; İnal ve ark., 1995). Bitki yapraklarında bulunan K miktarı ile tuzlu şartlarda bitkinin direncindeki artış arasında pozitif bir korelasyon vardır ve yüksek $\mathrm{K}^{+} / \mathrm{Na}^{+}$oranları tuza dayanıklılıkla doğru orantılıdır (Sherif ve ark., 1998). Bitki dokularında element bağlama yörelerinde Na ile özellikle $\mathrm{K}$ ve $\mathrm{Ca}$ gibi diğer katyonik elementlerin rekabete girmesinden dolayı $\mathrm{Na} / \mathrm{K}$ ve $\mathrm{Na} / \mathrm{Ca}$ dengesi hıla bozulmakta ve bu elementlerin alınımı ve taşınımı azalmaktadır. Bir çeşit $\mathrm{K}$ ve/veya $\mathrm{Ca}$ noksanlığ 1 yaratan bu durum, bitkide ozmoregülasyonu bozmakta, enzimlerin aktivasyonunu engellemekte ve metabolizma olumsuz etkilenmektedir. Bu gibi durumlarda dişarıdan potasyum takviyesi acil ve gerekli bir koşuldur. Bu koşul yerine getirildiğinde bitkinin stresten etkilenme derecesi azalmaktadır (Kaya ve Tuna, 2005).

Bitkilerin topraktan $\mathrm{K}^{+}$formunda aldıkları potasyum bitkilerde metabolik, fizyolojik ve biyokimyasal işlevlere sahip bir makro besin elementidir. Potasyum enzim aktivitesine, fotosenteze, bitki besin elementlerinin ve fotosentez ürünlerinin taşınmalarına yardım eder, protein kapsamını artırır, turgoru ve bitki su tüketimini dengeler. Potasyum ayrıca bitkilerde yatmayı önler, soğuğa, hastalık ve zararlılara karşı dayanıklılı̆̆ (1992) tarafindan bitkilerin tuza toleransını etkileyen faktörlerin araştırıldığı bir çalışmada bitkilerin tuza toleransının $\mathrm{Na}$ alımındaki sınırlandırma ile ilişkili olduğu ve bu sınırlandırmada potasyumun önemli rol oynadı̆̆ 1 belirlenmiştir. Ashraf ve ark. (1994) tuza toleranslı bitkilerin duyarlı olanlara oranla daha fazla $\mathrm{K}$ aldığını, kuraklık ve tuz baskısına toleransta potasyumun önemli rol oynadığını belirtmişlerdir. Özcan ve ark. (2000) ise tuz stresi altında bitkilerin prolin ve $\mathrm{Na}$ konsantrasyonları artarken, K kapsamlarının azaldığını bildirmişlerdir.

Toprak çözeltisinde yeterli oranda değişebilir $\mathrm{Ca}$ bulunmasının bir antogonist olarak sodyumun aktivitesini azalttığ 1 ve ortamda gelişen bitkilerin tuza dayanıklılığını arttırdığı bilinmektedir. Tuzluluğun önemli ölçüde sınırladığı bitki gelişimi de ortama $\mathrm{Ca}$ eklenmesiyle düzeltilebilmektedir. $\mathrm{Ca}$, membran geçirgenliğinin kontrolünde de etkin bir besin elementidir (Lauchli ve Grattan, 2007). Tuzlu şartlarda ortama ilave olarak verilen $\mathrm{Ca}$ ve potasyumun, $\mathrm{Na}$ ile rekabete girerek bitkiyi tuz etkisinden koruduğuna yönelik bir çalışmada; tuz stresi altındaki mısır bitkisinin toplam klorofil ve toplam karotenoid miktarları tuz uygulamasından olumsuz etkilenmiş, ancak besin çözeltisine ilave edilen kalsiyum, magnezyum ve potasyumlu bileşikler tuzun olumsuz etkisini kısmen hafifletmiş, kontrol ve tuz grubuna göre bitki gelişmesinde iyileştirici etki yapmışlardır (Yakıt ve Tuna, 2006). Diğer bir çalışmada Suhayda ve ark. (1990) tuz etkisi altındaki arpa bitkisinin yetişme ortamına ilave edilen kalsiyumun tuzlu ortamda gelişmeyi desteklediğini ve membran permeabilitesini düzenlediğini bildirmişlerdir.

Bitkiler büyüme ve gelişmeleri sürecinde gerçekleştirdikleri metabolik faaliyetleri ve çevresel faktörlerin de etkisiyle, serbest oksijen radikallerinin neden olduğu oksidatif strese maruz kalırlar. $\mathrm{Bu}$ tip bir stresin yoğun şartlarda etki etmesi ve bitkinin buna karşı bir savunma mekanizmasını devreye alamaması durumunda hücresel bazda hasar kaçınılmazdır. İşte bitkilerde de strese karşı serbest oksijen radikallerini detoksifikiye ederek onları inaktif şekle dönüştüren enzimatik antioksidant aktiviteleri yüksek olduğunda, bitkiler oksidatif zararı hafif bir şekilde atlatabilirler. Süperoksit dismütaz (SOD), peroksidaz (POX) ve katalaz (CAT) gibi enzimler serbest oksijen radikallerinin yok edilmesinde en etkin antioksidatif enzimler olarak bilinmektedirler (Karanlık, 2001). SOD; $\mathrm{O}_{2}{ }^{--}$nin dismutasyonu ile $\mathrm{H}_{2} \mathrm{O}_{2}$ oluşumunu sağlar. Sitosol, kloroplast, mitokondriyum ve peroksizom organellerinde bulunur. CAT; indirgeyiciye gereksinim duymadan 
$\mathrm{H}_{2} \mathrm{O}_{2}$ 'i detoksifiye eder. Mitokondriyum, peroksizom ve glikosizomda lokalize olmuştur. Sitosol ve mitokondriyumda yoğun olarak bulunan POX ise; indirgeyici olarak çeşitli substratları kullanarak $\mathrm{H}_{2} \mathrm{O}_{2}$ 'i detoksifiye eder (Y1lmaz ve ark., 2011).

Stres altındaki bitkilerin stresle mücadelesi onların ilgili stres tipine karşı olan dirençleriyle yakından ilişkilidir. Toleranslı genotiplerde stres ile karşılaşıldığında antioksidatif enzim aktiviteleri artarken, hassas genotiplerde genellikle azalır veya değişmez. Bu durum onların bir kalıtsal özelliğidir ve değişmez. Örneğin doğada kendiliğinden yetişen birçok bitki türü, kalıtsal olarak dirençli gruba girer. Kültür bitkilerinde de aynı türün varyeteleri arasında bile dirençli/hassas ayrımı olabilmektedir. Dirençli olanlar strese karş1 mukavemet göstererek yaşamsal faaliyetlerini aksamaya uğratmazlar. Yapılan bir çalışmada 5 farklı domates genotipine $150 \mathrm{mM} \mathrm{NaCl}$ stresi uygulanmış ve alınan sonuçlara göre; antioksidant enzim aktiviteleri toleranslı genotiplerde artarken, hassas genotiplerde azalmıştır. Lipit peroksidasyon (MDA) ve klorofil sonuçları da enzim aktivitelerini pozitif yönde desteklemiştir (Doğan, 2012). Antioksidant enzimlerin aktivitesindeki artışın birçok bitkide tuz toleransı ile yakından ilişkili olduğu bilinmektedir. Varılan ortak sonuç; bitki türlerinde antioksidant enzim aktivitesindeki artış ile oksidatif stres zararındaki azalma arasında önemli bir korelasyonun bulunduğu yönündedir (Yildız ve ark., 2010).

Bu çalışmada da önemli bir iç tüketim ve ihraç ürünü olan domates bitkisinin tuz stresi altında ilave olarak verilen potasyum ve kalsiyum uygulamalarına yanıtı araştırılmış ve bulgular irdelenmiştir.

\section{Materyal ve Yöntem}

Bu çalışma; Muğla Sıtkı Koçman Üniversitesi, Fen Fakültesi, Biyoloji Bölümü, Bitki Fizyolojisi Laboratuvarı'nda saksı denemesi şeklinde; 12 grup ve 3 tekerrürlü olmak üzere toplam 36 saksı ile yürütülmüş olup, deneme konuları aşağıda verilmiştir. 2 L'lik saksıların her biri 1:1 oranında $2 \mathrm{~kg}$ torf-dere kumu karışımı ile doldurulmuş, saksilara temel gübre olarak 5'er gr 18:18:18 (NPK içeren suda çözünebilir gübre) kompoze gübresi ilave edilmiştir. Aynı gün içinde her bir saksıya 2'şer domates fidesi dikilmiş ve ilk su verilerek çalışma başlatılmıştır.

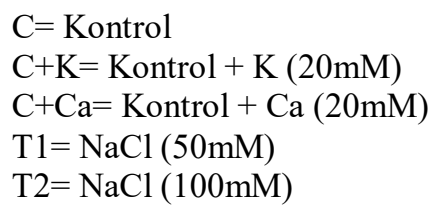

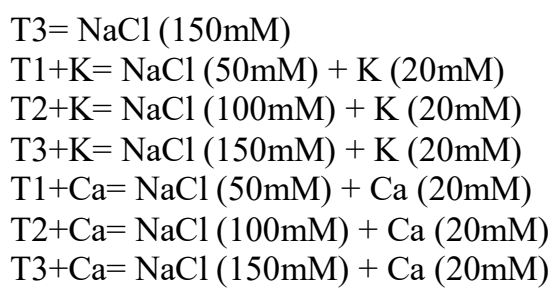

Bitkinin yetiştiği laboratuvar ortamı koşullarında fidelerin büyüme durumu göz önüne alınarak ilk tuz uygulamasına dikimden 15 gün sonra başlanmış ve ardından 1'er haftalık aralıklarla yaprak yoluyla potasyum ve kalsiyum verilmiştir. Potasyum, $\mathrm{KNO}_{3}$ (Potasyum nitrat; MA: $101 \mathrm{~g} \mathrm{~mol}{ }^{-1}$ ) formunda, kalsiyum ise $\mathrm{Ca}\left(\mathrm{NO}_{3}\right)_{2} \times 4 \mathrm{H}_{2} \mathrm{O}$ (Kalsiyum nitrat; MA: $236 \mathrm{~g}$ $\mathrm{mol}^{-1}$ ) formunda 20 'şer $\mathrm{mM}$ konsantrasyonlarında yapraktan uygulanmışlardır. Bitkinin büyüme sürecinde mikro element (Demir, Fe; bakır, $\mathrm{Cu}$; çinko, Zn; mangan, Mn ve bor, B) gereksinimini karşılamak amacıyla Fetrilon combi-I besin çözeltisi (\% 0.3'lük) yapraktan verilmiştir. Kontrol grubuna yalnız çeşme suyu, $\mathrm{NaCl}$ grubuna ise yalnız çeşme suyu içerisinde artan konsantrasyonlarda çözülen $\mathrm{NaCl}$ bitki yetişme ortamına verilmiştir.

Bitkilerin generatif evreye geçişiyle beraber 60 günün sonunda çalışma sonlandırılmıştır. Usulüne uygun bir şekilde yapraklar toplanmış ve etüvde 70 ${ }^{\circ} \mathrm{C}$ sicaklikta 72 saat boyunca kurutularak kuru ağırlık belirlenmiştir. Biyokimyasal analizler için gerekli olan yaprak örnekleri, önceden etiketlenen kilitli buzdolabı poşetlerine konularak $-18{ }^{\circ} \mathrm{C}$ dipfrize alınmıştır.

Yaprak örneklerinde; prolin kapsamı, ninhidrin reagent metoduyla (Bates ve ark., 1973); membran geçirgenliği (MG, \%), $1 \mathrm{~cm}$ çapındaki yaprak disklerinde EC metre ile (Lutts ve ark., 1996); nisbi su kapsamı (NSK, \%), yaprak disklerinde (Barrs ve Weatherley, 1962) belirlenmiștir. Süperoksit dismütaz (SOD), peroksidaz (POX) ve katalaz enzim aktiviteleri, fosforik buffer (pH:7)'de homojenize edilen ön enzim ekstraksiyonundan sonra; SOD, Beauchamp ve Fridovich (1971)'in belirlediği nitroblue tetrazoliumun fotokimyasal azalmayı inhibe etme kapasitesinin belirlenmesiyle; POX, Chance ve Maehly (1955) metoduna göre guaiacol oksidasyonu ile; CAT ise, Bergmeyer (1970) metoduna göre saptanmıştır. $\mathrm{H}_{2} \mathrm{O}_{2}$, trichloroacetic acid (TCA) metoduyla Loreto ve Velikova (2001)'e göre; lipit peroksidasyonu ise, Rao ve Sresty (2000)'e göre malondialdehit (MDA) ölçümü ile belirlenmiștir. Malondialdehit, lipit peroksidasyonunun son ürünüdür ve içeriği bu yöntemde tiyobarbitürik asit reaksiyonu kullanılarak belirlenmiştir. Elde edilen veriler; 
IBM SPSS Statistics 2.0 programı kullanılarak tek yönlü varyans analizine tabi tutulmuş ve ortalamaların karşılaştırılması LSD testiyle yapılmıştır.

\section{Bulgular ve Tartışma}

Yapraktan uygulanan $\mathrm{K}$ ve $\mathrm{Ca}$ besin elementlerine yanit olarak, $\mathrm{NaCl}$ etkisi altında bulunan domates bitkisinin yapraklarında belirlenen antioksidatif enzim aktiviteleri ve $\mathrm{H}_{2} \mathrm{O}_{2}$ kapsamlarına ait veriler Tablo 1'de sunulmuştur.

$\mathrm{NaCl}$ konsantrasyonları arttırıldıkça (T1, T2 ve T3; sirasiyla 50, 100 ve $150 \mathrm{mM}$ ) tüm enzim aktiviteleri ile MDA ve $\mathrm{H}_{2} \mathrm{O}_{2}$ kapsamlarının kontrol grubuna göre yükseldiği ve $\mathrm{NaCl}$ 'ün $\mathrm{T} 3$ konsantrasyonunda en yüksek değere ulaştığ1 belirlenmiştir. Kontrol grubuyla karşılaştırıldığında, T3'deki artış oranı SOD için yaklaşık olarak \% 420, POX için \% 460, CAT için $\%$ 460, MDA için \% 120 ve $\mathrm{H}_{2} \mathrm{O}_{2}$ için ise \% 150 oranlarında tespit edilmiştir. Domates bitkisine yapraktan uygulanan $\mathrm{K}$ ve Ca'un tuzluluğa bir yanıt olarak yükselmiş bulunan antioksidatif enzim aktiviteleri ve MDA oranını etkin bir şekilde düşürdüğü görülmektedir. T3 grubunda 27.5 olan SOD kapsamı, T3+K grubunda \% 50 oranında bir düşüşle 13.5'a, yine T3 grubunda 15.37 olan MDA kapsamı da \% 85 oranında düşüşle 7.05 değerine gerilemiştir. Diğer enzim aktivitelerinde de benzer sonuçlar görülmektedir. $\mathrm{K}$ ve Ca uygulamalarıyla gerileyen antioksidativ enzim aktivitelerine paralel olarak, hücresel hasarın bir göstergesi niteliğinde olan lipit peroksidasyon seviyesini gösteren MDA kapsamındaki azalmalar da dikkati çekmektedir. K ve $\mathrm{Ca}$ antioksidatif enzim aktivitelerini yaklaşık olarak eşit oranlarda düşürmelerine rağmen, MDA'in $\mathrm{K}$ uygulamasıyla daha etkili bir şekilde azaldığ1 tespit edilmiştir. Öyle ki, T3 grubuyla kıyaslandığında $\mathrm{T} 3+\mathrm{K} \quad$ uygulamasıyla $\mathrm{MDA}$ kapsamındaki düşüş yaklaşık olarak \% 55 iken, $\mathrm{T} 3+\mathrm{Ca}$ uygulamasiyla MDA kapsaminda belirlenen düşüş oranı $\% \quad 5$ civarında gerçekleşmiştir (Tablo 1).

Gelişme ortamında artan düzeydeki tuz konsantrasyonları matabolik elektron taşınımını bozarak serbest radikal kapsamında artışa neden olmaktadır. Söz konusu radikaller, başta lipitler olmak üzere nükleik asitler ve proteinler gibi makro/mikro moleküllere zarar vermektedir. Bu nedenle, hücresel serbest radikallerin detoksifikasyonu yaşamsal önem arz eder. İşte farklı bir çok araştırmadan elde edilen veriler, abiyotik strese maruz kalan bitkilerin tuz zararından sakınabilmek için (ilgili stres türüne dirençli veya hassas olmalarına bağlı olmak kaydiyla) SOD, CAT, POX ve benzeri antioksidan enzim aktivitelerini yükselttiklerini ve hücresel zarar kaynağı olan serbest radikalleri inaktif hale getirdiklerini rapor etmektedir (Yaşar ve ark., 2006, 2008; Aydemir ve Erez, 2010; Y1ldiz ve ark., 2010).

Konuyla ilgili yapılan çalışmalarda, domates, bezelye, buğday ve pirinç gibi bitki türlerinde antioksidant enzim aktivitesindeki artış ile oksidatif stres zararındaki azalma arasında önemli bir korelasyonun bulunduğu bildirilmiştir. Zhu ve ark. (2004) tuz stresi altında bulunan kabak bitkisinde CAT enzim aktivitelerinin düşerken, buna karşın SOD, POX ve GR aktivitelerinin arttığını; pamukta ise SOD, POD ve GR aktivitelerinin arttığı; CAT aktivitesinin ise azaldığını bildirmişlerdir. Bununla birlikte, tuz stresi altındaki bitkilerde antioksidant enzim aktivitesindeki artışın, toleranslı varyete veya çeşitlerde daha yüksek olduğu da rapor edilmiştir (Y1ldız ve ark., 2010).

Tablo 1. $\mathrm{NaCl}$ etkisi altındaki domates bitkisi yapraklarında antioksidatif enzim aktiviteleri, $\mathrm{H}_{2} \mathrm{O}_{2}$ ve MDA üzerine potasyum ve kalsiyumun etkisi*

\begin{tabular}{llcccc}
\hline Uygulamalar & $\begin{array}{c}\mathrm{SOD} \\
\left(\mathrm{m} \mathrm{g}^{-1} \text { protein }\right)\end{array}$ & $\begin{array}{c}\mathrm{POX} \\
\left(\Delta \mathrm{A} 470 \mathrm{~min}^{-1} \mathrm{mg}^{-1} \text { protein }\right)\end{array}$ & $\begin{array}{c}\mathrm{CAT} \\
\left(\mu \mathrm{M} \mathrm{H}_{2} \mathrm{O}_{2} \mathrm{~min}^{-1} \mathrm{FW}\right)\end{array}$ & $\begin{array}{c}\mathrm{MDA}^{\mathrm{A}} \\
\left(\mathrm{nM} \mathrm{g}^{-1} \mathrm{FW}\right)\end{array}$ & $\begin{array}{c}\mathrm{H}_{2} \mathrm{O}_{2} \\
\left(\mu \mathrm{M} \mathrm{g} \mathrm{FW}^{-1}\right.\end{array}$ \\
\hline $\mathrm{C}$ & $4.9 \pm 0.97 \mathrm{f}$ & $2.60 \pm 0.19 \mathrm{de}$ & $0.70 \pm 0.081 \mathrm{~d}$ & $6.97 \pm 1.17 \mathrm{de}$ & $4.76 \pm 1.07 \mathrm{ef}$ \\
$\mathrm{C}+\mathrm{K}$ & $5.0 \pm 1.13 \mathrm{ef}$ & $2.66 \pm 0.78 \mathrm{de}$ & $0.71 \pm 0.068 \mathrm{~d}$ & $6.87 \pm 1.18 \mathrm{de}$ & $5.37 \pm 1.41 \mathrm{de}$ \\
$\mathrm{C}+\mathrm{Ca}$ & $4.4 \pm 1.27 \mathrm{fg}$ & $2.32 \pm 0.56 \mathrm{e}$ & $0.62 \pm 0.045 \mathrm{de}$ & $6.53 \pm 1.25 \mathrm{e}$ & $5.11 \pm 1.73 \mathrm{e}$ \\
$\mathrm{T} 1$ & $6.7 \pm 1.14 \mathrm{e}$ & $3.57 \pm 0.21 \mathrm{~d}$ & $0.96 \pm 0.089 \mathrm{~cd}$ & $8.11 \pm 1.54 \mathrm{c}$ & $6.35 \pm 1.37 \mathrm{~d}$ \\
$\mathrm{~T} 2$ & $12.3 \pm 1.89 \mathrm{bc}$ & $6.54 \pm 0.49 \mathrm{bc}$ & $1.76 \pm 0.132 \mathrm{bc}$ & $10.23 \pm 1.69 \mathrm{~b}$ & $8.01 \pm 1.76 \mathrm{bc}$ \\
$\mathrm{T} 3$ & $27.5 \pm 2.15 \mathrm{a}$ & $14.75 \pm 1.84 \mathrm{a}$ & $3.92 \pm 0.657 \mathrm{a}$ & $15.37 \pm 1.94 \mathrm{a}$ & $12.03 \pm 1.95 \mathrm{a}$ \\
$\mathrm{T} 1+\mathrm{K}$ & $5.9 \pm 1.04 \mathrm{e}$ & $3.16 \pm 1.19 \mathrm{~d}$ & $0.85 \pm 0.078 \mathrm{~cd}$ & $8.64 \pm 1.67 \mathrm{c}$ & $6.76 \pm 1.24 \mathrm{~cd}$ \\
$\mathrm{~T} 2+\mathrm{K}$ & $10.9 \pm 1.73 \mathrm{~d}$ & $5.80 \pm 1.74 \mathrm{c}$ & $1.56 \pm 0.083 \mathrm{c}$ & $7.95 \pm 1.91 \mathrm{~cd}$ & $6.22 \pm 1.54 \mathrm{~d}$ \\
$\mathrm{~T} 3+\mathrm{K}$ & $13.5 \pm 1.2 \mathrm{~b}$ & $7.19 \pm 1.94 \mathrm{~b}$ & $1.93 \pm 0.067 \mathrm{~b}$ & $7.05 \pm 1.53 \mathrm{~d}$ & $5.52 \pm 1.53 \mathrm{de}$ \\
$\mathrm{T} 1+\mathrm{Ca}$ & $6.07 \pm 1.18 \mathrm{e}$ & $3.21 \pm 1.18 \mathrm{~d}$ & $0.86 \pm 0.085 \mathrm{~cd}$ & $8.63 \pm 1.84 \mathrm{c}$ & $6.75 \pm 1.58 \mathrm{~cd}$ \\
$\mathrm{~T} 2+\mathrm{Ca}$ & $9.05 \pm 1.97 \mathrm{de}$ & $4.79 \pm 1.84 \mathrm{~cd}$ & $1.29 \pm 0.189 \mathrm{c}$ & $9.75 \pm 1.82 \mathrm{bc}$ & $7.63 \pm 1.69 \mathrm{c}$ \\
$\mathrm{T} 3+\mathrm{Ca}$ & $14.3 \pm 2.02 \mathrm{~b}$ & $7.61 \pm 1.74 \mathrm{~b}$ & $2.04 \pm 0.563 \mathrm{~b}$ & $14.67 \pm 2.01 \mathrm{a}$ & $11.48 \pm 2.17 \mathrm{ab}$ \\
\hline
\end{tabular}

": Aynı harfle gösterilen ortalamalar arasındaki fark istatistiksel olarak önemli değildir (LSD \% 5). Çizelgedeki her bir veri üç tekrarın ortalaması \pm standart hata olarak verilmiştir. 
Abiyotik stres etkisi altında bulunan bitkilerde saptanan MDA biyomolekülü, hücre membranının fosfolipitleri düzeyinde oksidatif bir zararlanmanın göstergesi olarak değerlendirilmektedir. Tuza tolerant bitkilerde stres altında yüksek antioksidatif kapasite nedeniyle düşük MDA düzeyleri ve buna bağlı olarak daha 1lımlı lipit peroksidasyonu tespit edilirken, tuza hassas bitkilerde ise bunun tersi bir durum görülmektedir. Stresle birlikte domates, buğday, arpa, hardal ve daha birçok bitkide lipid peroksidasyon göstergesi olan MDA düzeyinin yükseldiği de bilinmektedir (Güneş ve ark., 2007).

Tuz stresinin etkilerine karşı bitki toleransının arttırılmasında farklı biyomoleküllerin, inorganiklerin kullanımı denenmektedir. Yapılan çalışmalarda tuz stresi altında çeşitli makro elementler $(\mathrm{K}, \mathrm{Ca})$ ve mikroelementler (Selenyum, $\mathrm{Se}$; Silisyum, Si), salisilik asit, askorbik asit, prolin, sekonder metabolitlerler, metil jasmonat, poliaminler ve çeşitli bitki büyüme düzenleyicilerinin kullanımının olumlu etkileri belirlenmiştir (Gökdoğan ve Bürün, 2015).

Tuz konsantrasyonu artmış olan bitki büyüme ortamlarında yüksek $\mathrm{Na}$ kapsamları nedeniyle $\mathrm{K}$ ve Ca kapsamları ile $\mathrm{K} / \mathrm{Na}, \mathrm{K} / \mathrm{Ca}$ oranları azalma göstermektedir. $\mathrm{Bu}$ durum, Babu ve ark. (2012) tarafindan domates bitkisinde yapılan bir araştırmayla teyit edilmiştir. Benzer bir diğer çalışmada ise, $\mathrm{NaCl}$ stresi altındaki domates bitkisine yapraktan uygulanan potasyumun tuzluluk nedeniyle yükselmiş bulunan MDA ve antioksidatif enzimlerin aktivitesini düşürerek, stresin zararlarını hafiflettiği ve büyüme parametrelerini olumlu etkilediği ve yine ayrıca potasyumun tuzun indüklediği oksidatif hasarlanmayı da etkili bir şekilde azalttığı rapor edilmiştir (Amjad ve ark., 2016).

$\mathrm{NaCl}$ etkisi altındaki domates bitkisinin yapraklarında tespit edilen prolin kapsamı ve $\%$ MG oranlarına ait veriler Şekil 1'de sunulmuştur. Uygulanan her üç $\mathrm{NaCl}$ konsantrasyonunda da yaprak prolin seviyelerinde düzenli bir artış görülürken, yapraktan uygulanan $\mathrm{K}$ ve Ca prolin kapsamlarında tedrici bir azalmaya neden olmuş, benzer bir eğilim, membran geçirgenliğinde de saptanmıştır. $\mathrm{NaCl}$ uygulanmasıyla birlikte yükselen \% MG oranı, ortama $\mathrm{K}$ ve $\mathrm{Ca}$ ilavesiyle düşmüş, fakat bu düşüşte $\mathrm{Ca}$, potasyuma göre daha etkili bulunmuştur.

Jan ve Hadi (2015) tuz stresi etkisinde bulunan ayçiçeği bitkisine yapraktan uygulanan potasyumun, yaprakların serbest prolin ve total fenol kapsamlarını arttırmak suretiyle bitkinin tuza toleransını geliştirdiğini bildirmişlerdir. Prolin aminoasidi, bitki savunma mekanizmasının en önemli bileșenlerinden birisidir. Tuz ve su stresi altındaki bitkilerde kapsamının arttığı ve böylece bitki savunma mekanizmasını harekete geçirerek bitkinin strese karș1 direncini desteklediği görüşü hâkimdir (Shannon, 1997). Tarımsal ekosistemde herhangi bir abiyotik stres etmeni ile karşılaşan bitkilerin olumsuz koşullara adapte olabilmek için bünyelerinde prolin miktarını artırdıkları belirtilmektedir (Hare ve Cress, 1997). Wang ve Han (2009) yonca çeşitleri ile yaptıkları çalışmada prolin birikiminin tuza toleransin bir sonucu olabileceğini belirtmiştir. Eraslan ve ark. (2016) in

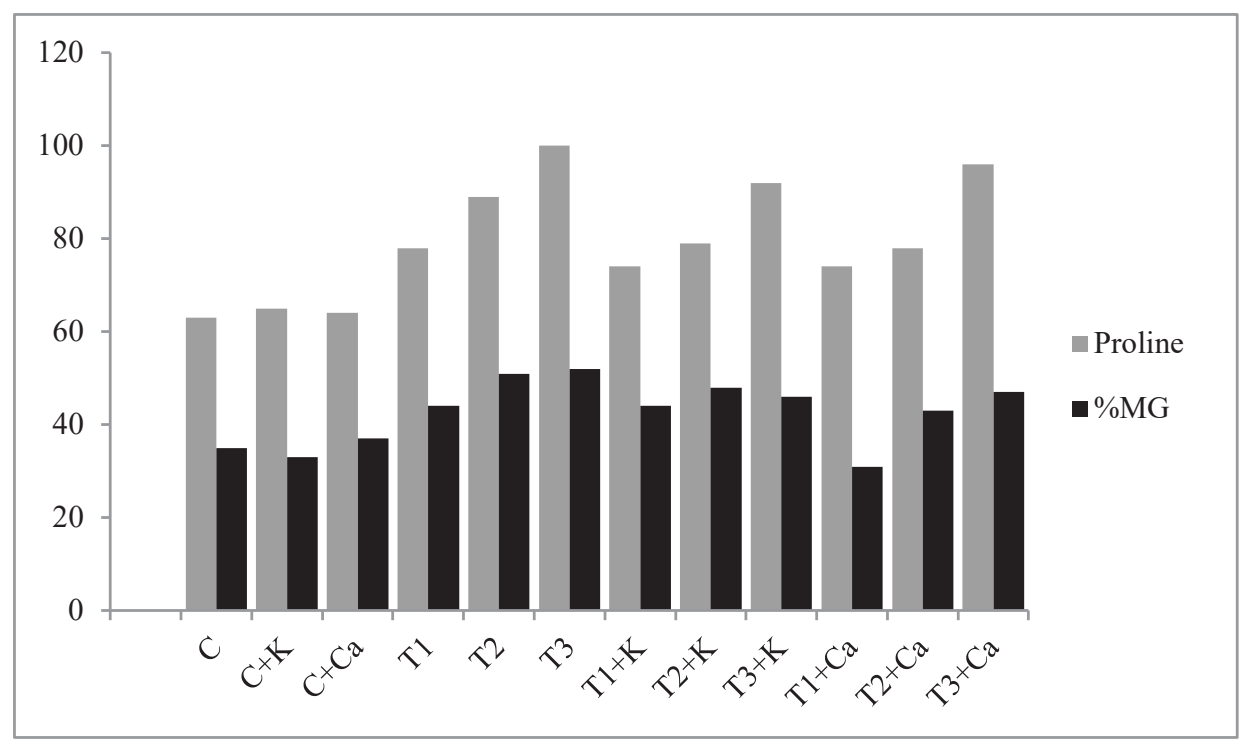

Şekil 1. $\mathrm{NaCl}$ etkisi altındaki domates bitkisi yapraklarında prolin ve \% MG üzerine potasyum ve kalsiyumun etkisi 
vitro tuz stresine maruz birakılan kiraz anaçlarında $\mathrm{NaCl}$ uygulamasının, sürgün gelişimi ve toplam klorofil içeriğini kontrole göre azaltırken MDA içeriğini, MG (membran geçirgenliği) ve prolin içeriğini arttırdığını rapor etmişlerdir.

Membran geçirgenliği veya elektriksel geçirgenlik, abiyotik stresle karşılaşan bitkilerde ozmotik uyumsuzluk nedeniyle bozulan iyon dengesizliği olarak tanımlanabilmektedir. Bu test, hücre membran stabilitesi hakkında ve apoplastik bölgelerdeki nispi iyon içeriği hakkında da değerli bilgiler vermektedir (Ghoulam ve ark., 2002; Yakıt ve Tuna, 2006). Tuz stresi altındaki birçok bitkide MG değerlerinin artış gösterdiği bildirilmektedir. Ghoulam ve ark. (2002) şeker pancarında, Lutts ve ark. (1996) pirinçte, Yakıt ve Tuna (2006) mısırda tuz stresi altında MG değerlerinde artış görüldüğünü rapor etmişlerdir. Yine tuz stresi altındaki bitkilere dışarıdan uygulanan makro besin elementlerinin $\mathrm{MG}$ değerleri üzerine iyileştirici etki yaptığı da bazı araştırıcılar tarafından bildirilmiştir. Kaya ve Higgs (2003) biber bitkisine ilave olarak verilen potasyumun ve yine Kaya ve Higgs (2002) hiyar bitkisine uygulanan kalsiyumun $\mathrm{MG}$ oranları üzerinde olumlu etki yaptığını rapor etmişlerdir.

Yaprak örneklerinin nispi su kapsamı (NSK) ve kuru madde (KM) oranlarına ait veriler Şekil 2'de sunulmuştur. Kontrolle karşılaştırıldığında her üç $\mathrm{NaCl}$ konsantrasyonunda da düzenli bir düşüş eğilimi söz konusudur. Fakat T3 (150 mM NaCl) konsantrasyonunda, düșüş agresif olup, kontrole kıyasla yaklașık olarak \% 45 azalmayı temsil etmektedir. Ortama K ve Ca ilavesi de bu agresif bozulmayı yeterince telafi edememiş görünmektedir. Öyle ki, T3 ile $\mathrm{T} 3+\mathrm{K}$ ve $\mathrm{T} 3+\mathrm{Ca}$ kıyaslandığında ortama ilave edilen potasyumun NSK oranını \% 44'ten \% 51'e, kalsiyumun ise \% 49'a yükselttiği belirlenmiştir. Yaprakların KM kapsamları da tuz uygulamalarıyla azalmış ve burada da en fazla düşüş yine T3 konsantrasyonunda saptanmıştır. Ortama ilave edilen $\mathrm{K}$ ve $\mathrm{Ca}$, yaprakların KM kapsamını 1lımlı bir oranda yükseltebilmiştir.

Kaya ve ark. (2001) tuz stresi altındaki ispanak bitkisine potasyum kaynağ1 olarak $\mathrm{KH}_{2} \mathrm{PO}_{4}$ uygulamışlar ve elde ettikleri verilere göre, yaprakların K kapsamlarının arttığını ve buna bağlı olarak da bitkinin nispi su içeriği, kuru madde oranı, membran geçirgenliği ve klorofil kapsamlarında iyileşme gözlendiğini bildirmişlerdir. Tuz stresi altındaki Atriplex bitkisinde $\mathrm{Na}$ ve $\mathrm{MG}$ oranında saptanan artışların, gelişme ortamına ilave $\mathrm{Ca} \quad\left(\mathrm{CaCl}_{2}\right.$ olarak $)$ uygulanmasıyla, yaprakların $\mathrm{Na}$ kapsamı ve $\mathrm{MG}$ oranını etkili bir şekilde düşürerek, başta kuru madde oranı olmak üzere bitki büyüme ve gelişme parametrelerini olumlu etkilediği bildirilmiștir (Nedjimi ve Daoud, 2009).

Kaya ve ark. (2002) tuz stresinin çilek bitkisindeki etkilerini araştırdıkları çalıșmalarında, $\mathrm{NaCl}$ etkisi altındaki bitkide kuru madde, meyve verimi ve klorofil kapsamının kontrole göre azaldığını ancak ortama ilave edilen kalsiyumun, söz konusu parametrelerdeki negatif eğilimi düzelttiğini bildirmişlerdir. Aynı araştırıcılar tuzluluk nedeniyle artan MG oranının da $\mathrm{Ca}$ uygulanmasıyla düştüğünü ve kalsiyumun çilek bitkisinin su kullanım oranını da tuzlu ortam şartlarında arttırdığını rapor etmişlerdir.

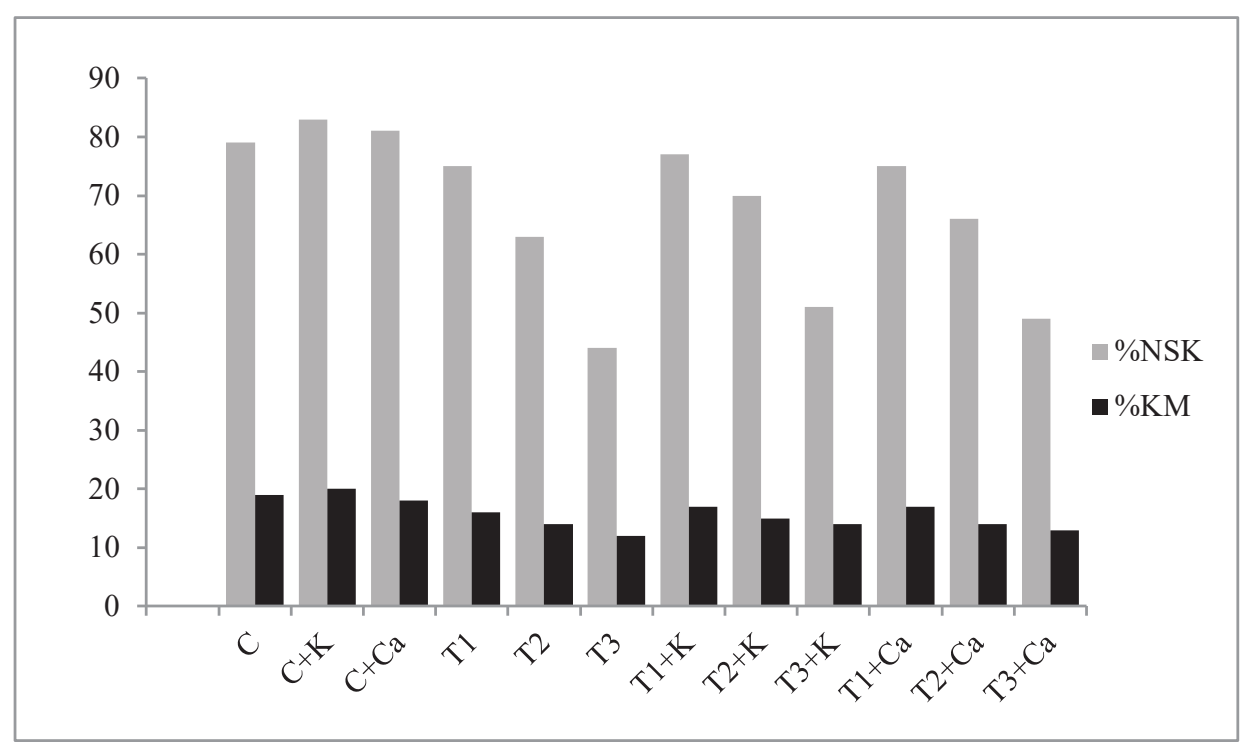

Şekil 2. $\mathrm{NaCl}$ etkisi altındaki domates bitkisi yapraklarında \% NSK ve \% KM üzerine potasyum ve kalsiyumun etkisi 


\section{Sonuçlar}

Yoğun bitkisel üretimin gerçekleştirildiği kapalı lokal tarımsal ekosistemlerde görülen toprak tuzluluğu üretimi kısıtlayıcı önemli bir faktör olmuştur. Her ne kadar moleküler düzeyde çalışmalarla tuzluluğa dirençli yeni bitki çeşitlerinin geliştirilmesi deneniyorsa da, bu konuda tatmin edici bir sonuca henüz ulașılamamıştır. Bu nedenle hafif ve orta düzeyde tuzlanmış topraklarda yetiştirilen bitkilerin zararlanmalarını önlemek adına, dışarıdan ilave olarak organik veya inorganik birçok madde denenmektedir. Ortak amaç $\mathrm{Na}$ alımının kısıtlanması ve hücresel zararın önlenmesidir. $\mathrm{Bu}$ çalışmada da bitkiler için vazgeçilmez iki önemli makro element olan $\mathrm{K}$ ve Ca uygulamalarının tuz etkisi altında bulunan domates bitkisinde antioksidatif sistem üzerine olası etkileri araştırılmıştır. Elde edilen sonuçlara göre özellikle seralarda başta domates olmak üzere kültür bitkisi tarımında, bitkilere uygun doz ve zamanlarda potasyum ve kalsiyum uygulamalarının antioksidatif sistemi uyarıp genel büyümeyi destekleyerek bitkileri olası zararlanmalardan koruyabileceği yargısına ulaşılmıştır.

\section{Kaynaklar}

Amacher, J.K., Koenig, R., Kitchen, B., 2000. Salinity and Plant Tolerance. Utah State University, Cooperative Extension, AG-SO-03.

Amjad, M., Akhtar, J., Anwar-ul-Haq, M., Riaz, M.A., Saqib, Z.A., Murtaza, B., Naeem, M.A., 2016. Effectiveness of potassium in mitigating the saltinduced oxidative stress in contrasting tomato genotypes. http://dx.doi.org/10.1080/01904167. 2016.1201107.

Ashraf, M., Zafar, Z.U., Cheema, Z.A., 1994. Effect of low potassium regimes on some salt and droughttolerant lines of pearl millet. Phyton, 34(2): 219-227.

Aydemir, T., Erez, Z., 2010. NaCl stresine karşı Lens culinars'in biyokimyasal ve fizyolojik cevabi. Celal Bayar Üniversitesi Fen Bilimleri Dergisi, 6(2): 89104.

Babu, M.A., Singh, D., Gothandam, K.M., 2012. The effect of salinity on growth, hormones and mineral elements in leaf and fruit of tomato cultivar PKM1. The Journal of Animal \& Plant Sciences, 22(1): 159164.

Barrs, H.D., Weatherley, P.E., 1962. A re-examination of the relative turgidity technique for estimating water deficits in leaves. Australian Journal of Biological Sciences, 15(3): 413-428.

Bates, L.S., Waldren, R.P., Teare, I.D., 1973. Rapid determination of free proline for water stres studies. Plant and Soil, 39(1): 205-207.

Beauchamp, C., Fridovich, I., 1971. Superoxide dismutase: Improved assays and an assay applicable to acrylamide gels. Anal Biochem, 44(1): 276-287.
Bergmeyer, H.U., 1970. Methoden der enzymatischen analyse. Akademie Verlag, 1: 636-647.

Chance, B., Maehly, A.C., 1955. Assay of catalase and peroxidases. Methods Enzymologia, 2: 764-775.

Doğan, M., 2012. Azot uygulamasının tuz stresi ve antioksidan enzim aktivitesine etkisi. Süleyman Demirel Üniversitesi Fen Bilimleri Enstitüsü Dergisi, 16(3): 297-306.

Eraslan, F., Arıcı, Ş.E., Erdal, İ., Küçükyumuk, Z., 2016. Kiraz Anaçlarının in vitro koşullarda tuz stresine tolerans mekanizmalarının fizyolojik parametreler ve antioksidan enzim izoformları ile belirlenmesi. Tartm Bilimleri Dergisi, 22: 117-128.

Ghoulam, C., Foursy, A., Fores, K., 2002. Effects of salt stress on growth, inorganic ions and proline accumulation in relation to osmotic adjustment in five sugar beet cultivars. Enviromental and Experimental Botany, 47(1): 39-50.

Gökdoğan, E.Y., Bürün, B., 2015. Ekolojik bir problem olarak toprak tuzluluğu ve bitkilerdeki etkileri. Anadolu Doğa Bilimleri Dergisi, 6(2): 70-76.

Güneş, A., İnal, A., Bağc1, E.G., Pilbeam, D., 2007. Silicon-mediated changes of some physiological and enzymatic parameters symptomatic for oxidative stress in spinach and tomato grown in sodic-B toxic soil. Plant and Soil, 290(1): 103-114.

Güneș, A., Post, W.H.K., Kirkby, E.A., Aktaș, M., 1994. Influence of partial replacement on nitrate by amino acid nitrogen or urea in the nutrient medium on nitrate accumulation in NFT grown winter lettuce. Journal of Plant Nutrition, 17(11): 1929-1938.

Hare, P.D., Cress, W.A., 1997. Metabolic implication of stress-induced proline accumulation in plants. Plant Growth Regulation, 21(2): 79-102.

İnal, A., Güneş, A., Aktaş, M., 1995. Effects of chloride and partial substitution of reduced forms of nitrogen for nitrate in nutrient solution of the nitrate, total nitrogen and chlorine contents of onion. Journal of Plant Nutrition, 18: 2219- 2227.

Jan, A.U., Hadi, F., 2015. Potassium, zinc and gibberellic acid foliar application enhanced salinity stress tolerance, proline and total phenolic in sunflower (Helianthus annuus L.). AmericanEurasian Journal of Agricultural and Environmental Sciences, 15(9): 1835-1844.

Kacar, B., 2005. Potasyumun bitkilerde işlevleri ve kalite üzerine etkileri. Ege Üniversitesi'nin 50. Kuruluş Yllı Etkinlikleri, Çalıştay, 3-4 Ekim, Eskişehir, s: 20-31.

Karanlık, S., 2001. Değişik buğday genotiplerinde tuz stresine dayanıklılık ve dayanıklılığın fizyolojik nedenlerinin araştırılması. Doktora tezi, Çukurova Üniversitesi Fen Bilimleri Enstitüsü, Adana.

Kaya, C., Higgs, D., Kirnak, H., 2001. The effects of high salinity and supplementary phosphorus and potassium on physiology and nutrition development of spinach. Bulgarian Journal of Plant Physiology, 27(3-4): 47-59.

Kaya, C., Tuna, A.L., 2005. Tarımda potasyumun yeri ve önemi. Ege Üniversitesi'nin 50. Kuruluş Yll 
Etkinlikleri, Çalıştay, 3-4 Ekim, Eskişehir, s: 164173.

Kaya, C., Kirnak, H., Higgs, D., Saltali, K., 2002. Supplementary calcium enhances plant growth and fruit yield in strawberry cultivars grown at high $(\mathrm{NaCl})$ salinity. Scientia Horticulturae, 93(1): 65-74.

Kaya, C., Higgs, D., 2002. Calcium nitrate as a remedy for salt-stressed cucumber plants. Journal of Plant Nutrition, 25(4): 861-871.

Kaya, C., Higgs, D., 2003. Supplementary $\mathrm{KNO}_{3}$ improves salt tolerance in bell pepper plants. Journal of Plant Nutrition, 26(7): 1367-1382.

Koyuncu, N., 2012. Bazı makarnalık buğday (T. durum) çeşitlerinin in vitro koşullarda yüksek tuz dozlarına tepkileri. Tarla Bitkileri Merkez Araştırma Enstitüsü Dergisi, 21(2): 70-74.

Lauchli, A., Grattan, S.R., 2007. Plant growth and development under salinity stress. In: M.A. Jenks, et al., (Eds), Advances in molecular breeding toward drought and salt tolerant crops, pp.1-32.

Litifi, A., Beek, J.G., Van-de-Beek, J.G., 1992. Capsicum-Newsletter. Special Issue, 51-56, Eucarpia VIII th. Meeting on Genetics and Breeding on Capsicum and Egg Plant, Rome, Italy, 7-10 September, 6 ref.

Loreto, F., Velikova, V., 2001. Isoprene produced by leaves protects the photosynthetic apparatus against ozone damage, quenches ozone products, and reduces lipid peroxidation of cellular membranes. Plant Physiology, 127(4): 1781-1787.

Lutts, S., Kinet, J.M., Bouharmont, J., 1996. NaClinduced senescence in leaves of rice (Oryza sativa L.) cultivars differing in salinity resistance. Annals of Botany, 78(3): 389-398.

Nedjimi, B., Daoud, Y., 2009. Effects of calcium chloride on growth, membrane permeability and root hydraulic conductivity in two Atriplex species grown at high (Sodium Chloride) salinity. Journal of Plant Nutrition, 32(11): 1818-1830.

Özcan, H., Turan, M.A., Koç, Ö., Çıkılı, Y., Taban, S., 2000. Tuz stresinde bazı nohut (Cicer aietinum L.) çeşitlerinin gelişimi ve prolin, sodyum, klor, fosfor ve potasyum konsantrasyonlarındaki değişimler. Turkish Journal Agriculture and Forestry, 24: 649654.

Rao, K.V.M., Sresty, T.V.S., 2000. Antioxidative parameters in the seedlings of pigeonpea (Cajanus cajan L.) in response to $\mathrm{Zn}$ and $\mathrm{Ni}$ stresses. Plant Science, 157(1): 113-128.

Shannon, M.C., 1997. Adaptation of plants to salinity. Advances in Agronomy, 60: 75-120.

Sherif, M.A., El-Beshbeshy, T.R., Richter, C., 1998 Response of some Egyptian varieties of wheat (Triticum aestivum L.) to salt stress through potassium application. Bulletin of Faculty of Agriculture University of Cairo, 49: 129-151.

Suhayda, C.G., Redmann, R.E., Harvey, B.L., Cipywnyk, A.L., 1990. Comparative response of cultivated and wild barley species to salinity stress and calcium supply. Crop Science Society of America, 32(1): 154-163.

Wang, X.S., Han, J.G., 2009. Changes of proline content, activity, and active isoforms of antioxidative enzymes in two alfalfa cultivars under salt stress. Agricultural Sciences in China, 8(4): 431440

Yakıt, S., Tuna, A.L., 2006. Tuz stresi altındaki misır bitkisinde (Zea mays L.) stres parametreleri üzerine $\mathrm{Ca}, \mathrm{Mg}$ ve K'nın etkileri. Akdeniz Üniversitesi Ziraat Fakültesi Dergisi, 19(1): 59-67.

Yaşar, F., Ellialtığlu, Ş., Özpay, T., Uza, Ö., 2008. Tuz stresinin karpuzda (Citrullus lanatus) antioksidatif enzim aktivitesi üzerine etkisi. Yüzüncü Yll Üniversitesi Ziraat Fakültesi Tarım Bilimleri Dergisi, 18(1): 61-65.

Yaşar, F., Kuşvuran, S., Ellialtıoğlu, S., 2006. Determination of antioxidant activities in some melon (Cucumis melo L.) varieties and cultivars under salt stress. Journal of Horticultural Sciences and Biotechnology, 81(4): 627-630.

Yıldız, M., Terzi, H., Cenkçi, S., Terzi, E.S.A., Uruşak, B., 2010. Bitkilerde tuzluluğa toleransın fizyolojik ve biyokimyasal markörleri. Anadolu Üniversitesi Bilim ve Teknoloji Dergisi - C Yaşam Bilimleri ve Biyoteknoloji, 1(1): 1-33.

Yılmaz, E., Tuna, A.L., Bürün, B., 2011. Bitkilerin tuz stresi etkilerine karșı geliştirdikleri tolerans stratejileri. Celal Bayar Üniversitesi Fen Bilimleri Dergisi, 7(1): 47-66.

Zhu, Z., Wei, G., Li, J., Qian, Q., Yu, J., 2004. Silicon alleviates salt stress and increases antioxidant enzymes activity in leaves of salt-stressed cucumber (Cucumis sativus L.). Plant Science, 167(3): 527533. 